${ }^{6}$ Buratti-de Hoghton R, Iqbal MJ. Total 17 hydroxyandrogens, $5 \alpha$ reduced hydroxyandrogens, and sex hormone binding globulin in assessing androgen dependent syndromes. In: Genazzani AR, Thijssen JHH, Siiteri PK, eds. Adrenal androgens. New York: Raven Press, 1980:301-7.

' Ismail AAA. Testosterone. In: Loraine JA, Bell ET, eds. Hormone assays and their clinical application. 4th ed. London: Churchill Livingstone, 1976:580-629.

${ }^{8}$ Vermeulen A, Rubens R, Verdonck L. Testosterone secretion and metabolism in male senescence. $\mathcal{F}$ Clin Endocrinol Metab 1972;34:730-5.

9 Greenway B, Duke D, Pym B, Iqbal MJ, Johnson PJ, Williams R. The control of human pancreatic adenocarcinoma xenografts in nude mice by hormone therapy. Br f Surg 1982;69:595-7.
10 Miller WR, Hawkins RA, Forrest APM. Steroid metabolism and oestrogen receptors in human breast carcinomas. Eur $\mathcal{F}$ Cancer Clin Oncol 1981; 17:913-7.

11 Bulbrook RD, Hayward JL, Spicer CC. Relation between urinary androgen and corticoid excretion and subsequent breast cancer. Lancet 1971 ;ii: 395-8.

12 England PC, Skinner LG, Cottrell KM, Sellwood RA. Serum oestradiol$17 \beta$ in women with benign and malignant breast disease. $\mathrm{Br} \mathcal{F}$ Cancer $1974 ; 30: 571-6$.

(Accepted 13 October 1982)

\title{
Changes in clinical features of coeliac disease in adults in Edinburgh and the Lothians 1960-79
}

\author{
RICHARD F A LOGAN, GEORGE TUCKER, EDITH A RIFKIND, ROBERT C HEADING, \\ ANNE FERGUSON
}

\begin{abstract}
From 1960 to 1979 there was a threefold increase in the number of cases of coeliac disease diagnosed annually in adults in Edinburgh and the Lothians. Women accounted for $80 \%$ of the increase and their mean age at diagnosis was significantly reduced. The ratio of female to male new cases changed from 1.25 in the '60s to 2.5 in the '70s. In the period $1975-956$ of 102 adults with coeliac disease presented with no gastrointestinal symptoms, including 30 cases diagnosed as a result of minor biochemical or haematological abnormalities, such as redcell macrocytosis without anaemia. Over the same period, only 13 presented with a typical malabsorption syndrome compared to 24 of $38(63 \%)$ in the years $1960-4$. During 1975-9 58 new cases had no anaemia, compared with eight $(21 \%)$ in the earlier period. Hypoproteinaemia (concentration $<60 \mathrm{~g} / 1$ ) and hypocalcaemia of $<2.00$ mmol/1 $(8 \mathrm{mg} / 100 \mathrm{ml})$ were also less common.

Though a real increase in the incidence of coeliac disease cannot be discounted, these changes are more likely to be the result of greater awareness of the disease and a lowered threshold for investigation.
\end{abstract}

\section{Introduction}

With the introduction of peroral jejunal biopsy for the diagnosis of coeliac disease estimates of the prevalence of the disease in the United Kingdom have steadily risen from 1 in 8000, suggested in 1950 , to recent estimates in children of around 1 in $1000 .{ }^{12}$ In 1979 the crude prevalence in Edinburgh and the

University of Edinburgh Gastrointestinal Unit, Western General Hospital, Edinburgh EH4 2XU

RICHARD F A LOGAN, MSC, MRCP, senior registrar (now: Wellcome research fellow, department of therapeutics, University of Nottingham, City Hospital, Nottingham)

EDITH A RIFKIND, BSC, research associate

ANNE FERGUSON, PHD, MRCPATH, reader in medicine and honorary consultant physician

Department of Therapeutics, Royal Infirmary, Edinburgh EH3 9YW GEORGE TUCKER, MB, FRACP, registrar

ROBER'T C HEADING, MD, FRCPE, senior lecturer and honorary consultant physician
Lothians was $61 / 100000$ ( 1 in 1637) with a peak of $90 / 100000$ in the age group 5-14 years. ${ }^{3}$ While textbook descriptions of coeliac disease emphasise features such as diarrhoea, weight loss, anaemia, and malabsorption, recent series have drawn attention to the numbers presenting with trivial, often unrelated, illness. ${ }^{45}$ Although it is generally assumed that the rising prevalence reflects increased awareness and improved diagnosis, the apparent decline in coeliac disease in childhood reported recently from Glasgow and Leeds suggests that pronounced changes in incidence may be occurring. ${ }^{6} 7$ Increased awareness of any chronic disease may increase numbers and also lead to a decline in severity at diagnosis and to earlier diagnosis.

We describe the current presentation of coeliac disease in adults in Edinburgh and Lothian and, by comparison with an earlier period, attempt to determine whether there has been any change in severity that might account, at least in part, for a rise in prevalence.

\section{Methods}

In 1979 a register of patients with coeliac disease was established in Edinburgh and the Lothians. The population of Lothian Region at the time of the 1971 census was 746000 . Cases of coeliac disease were identified from the records of the gastrointestinal units at the Royal Infirmary of Edinburgh and the Western General Hospital; hospital discharge records (Scottish Hospital In-patient Statistics); the histopathology records of the four pathology laboratories in the region from 1955 to 1980 ; and a postal survey of all general practitioners in Edinburgh and the Lothians. For all patients included in the register a clinical diagnosis of coeliac disease has been substantiated by abnormal findings at jejunal biopsy. All biopsy specimens were reviewed by one of two pathologists (Dr A Busuttil, Dr H Gilmour) without knowledge of the clinical details.

Patients who had dermatitis herpetiformis were recorded separately and have been excluded from this report. The study is confined to those patients in whom coeliac disease was diagnosed after their 15th birthday, and who are therefore classified as adults with coeliac disease; patients re-presenting because of a lapse in treatment of childhood coeliac disease have been excluded.

An analysis of sex, age, and year of diagnosis was performed on all of the adults registered. In addition, a more detailed analysis of clinical features was performed on those presenting to the two major teaching hospitals in the region, the Royal Infirmary and the Western General Hospital. These patients fulfilled two criteria : an appropriate abnormal finding on jejunal biopsy and a clinical or histopathological response to a gluten-free diet.

The date of diagnosis has been taken as the time of clinical diagnosis, which also was the date of the first abnormal finding at biopsy in al but three cases in the 1960-4 period and in all cases in the 1975-9 
period. The results of investigations performed at the time of first attendance at hospital or closest to that time have been used to determine investigative abnormalities. For the purposes of this study, presentation as overt malabsorption syndrome has been defined as "symptoms of diarrhoea and weight loss with either anaemia of $<10 \mathrm{~g} / \mathrm{dl}$, hypoproteinaemia of $<60 \mathrm{gm} / \mathrm{l}$, or hypocalcaemia of $<2.00 \mathrm{mmol} / 1(8 \mathrm{~g} / 100 \mathrm{ml})$." Tests of significance have been performed using the unpaired $t$ test and $\chi^{2}$ test with Yates's correction.

\section{Results}

Table I gives the number of cases of coeliac disease in adults diagnosed in all hospitals in the Lothians for the years 1960-79. A total of 47 cases (21 men, 26 women) were diagnosed in 1960-4 and a total of 138 ( 41 men, 97 women) in 1975-9. Whereas the number of cases diagnosed in men in each five-year period has increased only since 1975, the number of cases in women increased steadily over the whole period. The ratio of women to men increased from 1.25 in the 1960 s to 2.5 in the 1970 s $\left(\chi^{2}=6.83, p<0.01\right)$.

The table also shows the mean age at diagnosis for each group with the age distribution. For men, mean age at diagnosis has not changed significantly during the 20 years of the study. Mean age at diagnosis for women fell from 47.9 in the 1960 s to 41.8 in the 1970 s (unpaired $t$ test, $\mathrm{t}=2 \cdot 73, \mathrm{p}<0 \cdot 01)$.

TABLE I-Cases of coeliac disease in adults diagnosed in Edinburgh and the Lothians $1960-79$ by sex and age

\begin{tabular}{|c|c|c|c|c|}
\hline & $1960-4$ & $1965-9$ & $1970-4$ & $1975-9$ \\
\hline $\begin{array}{l}\text { Men: } \\
15-24 \\
25-34 \\
35-44 \\
45-54 \\
55-64 \\
65-74 \\
75-84\end{array}$ & $\begin{array}{r}0 \\
2 \\
3 \\
13 \\
1 \\
2 \\
0\end{array}$ & $\begin{array}{l}3 \\
4 \\
3 \\
8 \\
7 \\
2 \\
0\end{array}$ & $\begin{array}{l}2 \\
2 \\
5 \\
2 \\
3 \\
5 \\
0\end{array}$ & $\begin{array}{r}3 \\
6 \\
8 \\
10 \\
9 \\
3 \\
2\end{array}$ \\
\hline $\begin{array}{c}\text { Total } \\
\text { Mean } \pm \text { SD (years) }\end{array}$ & $\begin{array}{c}21 \\
48 \cdot 7 \pm 9 \cdot 8\end{array}$ & $\begin{array}{c}27 \\
45 \cdot 7 \pm 16 \cdot 1\end{array}$ & $\begin{array}{c}19 \\
47 \cdot 6 \pm 17 \cdot 0\end{array}$ & $\begin{array}{c}41 \\
47 \cdot 5 \pm 15 \cdot 7\end{array}$ \\
\hline $\begin{array}{c}\text { Women: } \\
15-24 \\
25-34 \\
35-44 \\
45-54 \\
55-64 \\
65-74 \\
75-84\end{array}$ & $\begin{array}{l}0 \\
4 \\
5 \\
6 \\
9 \\
2 \\
0\end{array}$ & $\begin{array}{r}2 \\
6 \\
7 \\
6 \\
11 \\
3 \\
0\end{array}$ & $\begin{array}{r}9 \\
13 \\
11 \\
5 \\
12 \\
2 \\
0\end{array}$ & $\begin{array}{r}12 \\
22 \\
21 \\
13 \\
22 \\
6 \\
1\end{array}$ \\
\hline $\begin{array}{l}\text { Total } \\
\text { Mean } \pm \mathrm{SD} \text { (years) }\end{array}$ & $\begin{array}{c}26 \\
48 \cdot 8 \pm 12 \cdot 1^{*}\end{array}$ & $\begin{array}{c}35 \\
47 \cdot 2 \pm 14 \cdot 0\end{array}$ & $\begin{array}{c}52 \\
40 \cdot 9 \pm 14 \cdot 3\end{array}$ & $\begin{array}{c}97 \\
42 \cdot 2 \pm 15 \cdot 9 *\end{array}$ \\
\hline
\end{tabular}

${ }^{*} t=1.97,0.05<p<0.06$.

\section{CLINICAL FEATURES}

Table II shows the clinical features of all adults with coeliac disease referred to the Royal Infirmary and Western General Hospital, Edinburgh in 1960-4 (38 cases) and 1975-9 (102 cases).

Mode of presentation-Using the term malabsorption syndrome as defined above, the number of cases of coeliac disease presenting as an overt malabsorption syndrome has fallen absolutely as well as proportionally between the two five-year periods $\left(\chi^{2}=33.64, p<0.001\right)$ This change affected both sexes. Clinical presentation as a result of symptoms from anaemia, osteomalacia, or hypocalcaemia occurred virtually only in women and the proportion of those presenting in this way showed no significant change. Although the number of patients presenting with diarrhoea but without overt evidence of malabsorption has risen, the increase in the proportion of those presenting in this way is not significant $\left(\chi^{2}=0.77, p>0.10\right)$. In the period 1975-9, a total of 41 of the 102 patients complained of diarrhoea, a further four presented with complications of the disease and had abdominal pain or dysphagia, and one presented with dyspeptic symptoms. The remaining 56 patients had no gastrointestinal symptoms.

Weight loss and small stature-In 1975-9 six patients presented with problems of weight loss without diarrhoea. Coeliac disease was suspected in four of these because of the presence of an associated condition (possible childhood coeliac disease in two, small stature in one, and fibrosing alveolitis in the fourth). In the remaining two cases selective IgA deficiency and red-cell macrocytosis led to jejunal
TABLE II-Clinical presentation of adults with coeliac disease referred to the Royal Infirmary and Western General Hospital, Edinburgh

\begin{tabular}{|c|c|c|c|c|c|c|}
\hline & \multicolumn{2}{|c|}{ Men } & \multicolumn{2}{|c|}{ Women } & \multicolumn{2}{|c|}{ Total } \\
\hline & $1960-4$ & $1975-9$ & $1960-4$ & $1975-9$ & $1960-4$ & $1975-9$ \\
\hline Malabsorption syndrome & 14 & 4 & 10 & 9 & 24 & 13 \\
\hline $\begin{array}{l}\text { Anaema or calcium } \\
\text { malabsorption } \\
\text { Diarrhoea and weight loss }\end{array}$ & $\begin{array}{l}1 \\
4\end{array}$ & $\begin{array}{l}0 \\
8\end{array}$ & $\begin{array}{l}6 \\
3\end{array}$ & $\begin{array}{l}15 \\
20\end{array}$ & 7 & $\begin{array}{l}15 \\
28\end{array}$ \\
\hline $\begin{array}{l}\text { stature } \\
\text { Minor blood abnormality } \\
\text { Associated condition }\end{array}$ & & $\begin{array}{l}4 \\
8 \\
3\end{array}$ & & $\begin{array}{r}5 \\
22 \\
4\end{array}$ & & $\begin{array}{r}9 \\
30 \\
7\end{array}$ \\
\hline Mean age (years) & $47 \cdot 3$ & $45 \cdot 9$ & $49 \cdot 3$ & $40 \cdot 3$ & $48 \cdot 3$ & $41 \cdot 8$ \\
\hline Total & 19 & 27 & 19 & 75 & 38 & 102 \\
\hline
\end{tabular}

biopsy. Investigation of short stature alone identified three cases of coeliac disease, two of whom are men. A further six women who presented with other features were noted to be short, all being shorter than 5 foot $(1.5 \mathrm{~m})$.

Minor biochemical or haematological abnormalities-During 1975-9, 30 cases of coeliac disease were identified as a consequence of minor abnormalities found on routine blood tests. None of these patients had diarrhoea or symptoms due to anaemia, osteomalacia, or hypocalcaemia. In 13 cases (11 women) the abnormality was red-cell macrocytosis (mean cell volume $>98 \mathrm{fl}$ ) without anaemia (haemoglobin $>11.5 \mathrm{~g} / \mathrm{dl}$ in women, $>13.0 \mathrm{~g} / \mathrm{dl}$ in men). In a further 10 cases (seven women) anaemia ranging from 7 to $11 \mathrm{~g} / \mathrm{dl}$ was found on routine screening tests and in eight was due to iron deficiency. In this group were three men and one woman who were investigated after being twice rejected as blood donors because of mild anaemia. Three women were investigated because a blood film showed features suggesting hyposplenism. Three men and one woman were investigated because of small increases in their serum alkaline phosphatase activity (range 109-196 IU/1), which in two cases was associated with mild hypocalcaemia (serum calcium $1.9 \mathrm{mmol} / 1(7.6 \mathrm{mg} / 100 \mathrm{ml})$ and $2.03 \mathrm{mmol} / \mathrm{l}$ $(8 \cdot 1 \mathrm{mg} / 100 \mathrm{ml})$ ).

Associated conditions-During 1975-9, seven cases were identified because of conditions now known to be associated with coeliac disease: recurrent aphthous ulceration in two cases and jejunal ulceration and stricturing in another two. Of the remaining three, one man had malignant histiocytosis of the small bowel, one woman had an oesophageal cancer and rickets, and one man underwent jejunal biopsy as part of a research study on eczema.

\section{RESULTS OF ROUTINE INVESTIGATIONS}

Anaemia (table III) - In all cases, at least one measurement of haemoglobin at the time of diagnosis was available. Between the two periods there was a trend towards less severe or no anaemia at presentation. The greatest proportional increase occurred in those presenting with a normal haemoglobin concentration $\left(\chi^{2}=12.85\right.$, $\mathrm{p}<0.001)$. These changes have affected both sexes but have been greater in women where the proportion without anaemia has risen from $11 \%$ to $60 \%$. In parallel with the number of patients presenting with symptoms of anaemia, moderate or severe anaemia was found more often in women (23 of 94) than in men (six of 46), but this difference was not significant.

Hypoproteinaemia and hypoalbuminaemia (table IV)-Information on serum or plasma protein and albumin concentrations was not available for all patients. As shown in table IV, the total frequency of

TABLE III-Frequency of anaemia in patients referred to Royal Infirmary and Western General Hospital, Edinburgh

\begin{tabular}{|c|c|c|c|c|c|c|}
\hline & \multicolumn{2}{|c|}{ Men } & \multicolumn{2}{|c|}{ Women } & \multicolumn{2}{|c|}{ Total } \\
\hline & $1960-4$ & $1975-9$ & $1960-4$ & $1975-9$ & $1960-4$ & $1975-9$ \\
\hline & $\overline{\text { No } \%}$ & $\overline{\text { No } \%}$ & No $\%$ & No $\%$ & No $\%$ & No $\%$ \\
\hline $\begin{array}{l}\text { Normal haemoglobin }{ }^{*} \\
\text { Mild anaemia }{ }^{\dagger} \\
\text { Moderate anaemia }+\end{array}$ & $\begin{array}{r}6(32) \\
10(53) \\
3(16)\end{array}$ & $\begin{array}{r}13(48) \\
11(41) \\
3(11)\end{array}$ & $\begin{array}{l}2(11) \\
9(47) \\
8(42)\end{array}$ & $\begin{array}{l}45(60) \\
15(20) \\
15(20)\end{array}$ & $\begin{array}{r}8(21) \\
19(50) \\
11(29)\end{array}$ & $\begin{array}{l}58(57) \\
26(26) \\
18(18)\end{array}$ \\
\hline Total & 19 & 27 & 19 & 75 & 38 & 102 \\
\hline
\end{tabular}

$*$ Men $>13 \mathrm{~g} / \mathrm{dl}$, women $>11.5 \mathrm{~g} / \mathrm{dl}$. †Men $11-13 \mathrm{~g} / \mathrm{dl}$, women $10-11.5 \mathrm{~g} / \mathrm{dl}$. $\ddagger$ Men $<11 \mathrm{~g} / \mathrm{dl}$, women $<10 \mathrm{~g} / \mathrm{dl}$. 
hypoproteinaemia has fallen considerably $\left(\chi^{2}=26.16, p<0.001\right)$ as has the frequency of hypoalbuminaemia.

Hypocalcaemia (table IV)-In the absence of simultaneous serum albumin measurements minor degrees of hypocalcaemia were difficult to assess. Hypocalcaemia of $<2.00 \mathrm{mmol} / 1(8 \mathrm{mg} / 100 \mathrm{ml})$ was uncommon in either five-year period, the proportion falling from $31 \%$ to $13 \%\left(x^{2}=3 \cdot 72, \mathrm{p} \quad 0.05\right)$.

TABLE IV-Frequency of biochemical abnormalities

\begin{tabular}{|c|c|c|c|c|c|c|}
\hline & \multicolumn{2}{|c|}{ Men } & \multicolumn{2}{|c|}{ Women } & \multicolumn{2}{|c|}{ Total } \\
\hline & $1960-4$ & $1975-9$ & $1960-4$ & $1975-9$ & $1960-4$ & $1975-9$ \\
\hline & $\overline{\operatorname{No}\left({ }_{0}^{*}{ }^{*}\right)}$ & $\overline{\operatorname{No}\left({ }^{0}{ }_{0}^{*}\right)}$ & $\overline{\operatorname{No}\left({ }^{\circ} 0^{*}\right)}$ & $\overline{\mathrm{No}\left({ }^{\circ}{ }^{*}\right)}$ & $\overline{\mathrm{No}\left(0^{\circ}{ }^{*}\right)}$ & $\overline{\operatorname{No}\left({ }^{0}{ }_{0}^{*}\right)}$ \\
\hline \multirow{3}{*}{$\begin{array}{l}\text { Total serum protein } \\
\quad 60 \mathrm{~g} / \mathrm{l} \\
\text { Serum albumin } \\
\quad 35 \mathrm{~g} / 1 \\
\text { Serum calcium } \\
\quad 2.00 \mathrm{mmol} / 1\end{array}$} & $13(77)$ & $2(8)$ & $6(38)$ & $8(12)$ & $19(58)$ & $10(11)$ \\
\hline & $11(92)$ & $4(17)$ & $6(46)$ & $14(22)$ & $17(68)$ & $18(20)$ \\
\hline & $7(41)$ & $0(0)$ & $2(17)$ & $11(17)$ & $9(31)$ & $11(13)$ \\
\hline
\end{tabular}

* = Expressed as percentage of available measurements

Conversion: SI to traditional units-Calcium: $1 \mathrm{mmol} / 1 \approx 4 \mathrm{mg} / 100 \mathrm{ml}$

\section{Discussion}

Since 1960 there has been a threefold increase in the number of adults presenting each year with coeliac disease. This increase has occurred in a region of Scotland where the total population growth has been less than $5 \%$. To obtain reasonable numbers of patients for the earlier period we included those who were not resident in the Lothians at the time of diagnosis. In recent years, with the development of district general hospitals, referrals from outwith the region have decreased but exclusion of these cases leaves a similar rate of increase. Thirty-two of the 47 patients diagnosed as having coeliac disease during 1960-4 and 121 of the 138 during 1975-9 were resident in the Lothians. Any retrospective analysis based on routine clinical records will invariably necessitate selection for those records that can be traced. No clinical record could be found for four cases in the 1960-4 period although results of a diagnostic jejunal biopsy were available; such a small number is unlikely to have introduced any appreciable bias.

The recent increase in number of adults with coeliac disease could be due either to an increase in the incidence of the disease or to an increased clinical awareness, and improved diagnosis, of a disease with a long, fluctuating, and often subclinical course. ${ }^{8}$ In the absence of any method of population screening for coeliac disease the true incidence of the disease cannot be determined. In contrast, we have provided evidence of diagnosis with increasingly mild illness and, for women, at an earlier age. This is in keeping with the hypothesis that earlier recognition of the disease accounts for at least some, if not all, of the increase.

The findings of this study, which is based on a relatively stable and well-defined population, support those from Northwick Park, where Swinson and Levi found that only $26 \%$ of their patients with coeliac disease presenting in the 1970s had classic symptoms of steatorrhoea, osteomalacia, or anaemia. ${ }^{4}$ They also found that in $44 \%$ of 88 cases the disease was suspected only because of an unexplained abnormality on a full blood count, which in a half was red-cell macrocytosis without anaemia. We could not compare the frequency and severity of steatorrhoea in the two periods as faecal fat was estimated in only 37 of the 102 cases in 1974-9 compared with 33 of 38 in the first. Of these, three in the first and seven in the second period were within the normal range. The diversity of clinical presentation of coeliac disease, which has been emphasised by Barry, ${ }^{8}$ is underlined by our finding that $55 \%$ of recent cases had no gastrointestinal symptoms to attract attention to the relevant system. Even in the 28 patients with diarrhoea but without obvious malabsorption, eight were initially diagnosed as having irritable bowel syndrome until an unexpected minor blood abnormality led to jejunal biopsy.
Current indications for jejunal biopsy should take into account the wide range of presenting symptoms of this disease. If the technique is used only when patients have classic malabsorption syndrome, many cases will remain undetected. That this in fact occurs is suggested by the considerable geographic variation in England and Wales in membership of the Coeliac Society, and by the correlation between membership of the Coeliac Society and sales of jejunal biopsy capsules. ${ }^{4}$

Although women outnumbered men by two to one in this study, the clinical features of the disease were very similar in both sexes. A greater proportion of women presented with anaemia or calcium malabsorption and men tended to have less severe anaemia. Otherwise, there were no significant sex-related differences. No consistent pattern emerged when the results for the two hospitals were compared, except in the diagnosis of coeliac disease in patients with associated conditions, a phenomenon which reflects referral to one of us with a particular interest in the disease (AF). The excess of women over men has been found in other series but, possibly because of their selected nature, has aroused little comment. ${ }^{4} 9$ Among 1075 new adult members of the Coeliac Society the ratio of women to men was $2 \cdot 02 .{ }^{9}$ These findings are in contrast to those in children with coeliac disease, where most series report a ratio close to one. In Lothian 145 girls and 116 boys have been registered as having coeliac disease and among 453 new child members of the Coeliac Society the ratio of girls to boys was $1 \cdot 06 .{ }^{9}$ The possibility that the true incidence of coeliac disease in men is much less than that in women cannot be dismissed, but the sex ratio in children with coeliac disease argues against it. The difference in adults may be partly due to increased nutritional demands of women during the reproductive years. Such an explanation is consistent with our finding that presentation as a result of symptoms of anaemia or calcium malabsorption occurred predominantly in women. This can only be a partial explanation, however, as the distribution of age at diagnosis shows that the excess of women persists in the older age groups. Another factor to be considered is the relative frequencies with which men and women use health services. If, as seems likely, the explanation for the sex ratio in adult coeliac disease is not differences in incidence but in diagnosis, then perhaps as many as half of men with adult coeliac disease remain undiagnosed.

We thank Dr A Busuttil and Dr Hugh Gilmour for reviewing all the jejunal biopsy specimens; the many physicians in Lothian Region who gave permission to study their patients; and the records officers and records staff of the hospitals in Lothian Region, whose success in tracing clinical records has been remarkable.

This study was supported by grants from the Scottish Home and Health Department and the Wellcome Trust.

\section{References}

${ }^{1}$ Davidson LSP, Fountain JR. Incidence of the sprue syndrome with some observations on the natural history. Br Med F 1950;i:1157.

${ }^{2}$ Arthur LJH, Langman MJS. Prevalence of coeliac disease in Derby. In: McConnell RB, ed. The genetics of coeliac disease. Lancaster: MTP Press, 1981:15-7.

${ }^{3}$ Rifkind EA, Logan RFA, Busuttil A, Gilmour H, Ferguson A. Coeliac disease in Edinburgh and the Lothians 1900-1980. Scott Med F 1982; $27: 256$.

4 Swinson CM, Levi AJ. Is coeliac disease underdiagnosed ? Br Med $\mathcal{F}$ $1980 ; 281: 1258-60$.

5 Mann JG, Brown WR, Kern F. The subtle and variable clinical expression of gluten induced enteropathy (adult coeliac disease). Am F Med 1970; 48:357-66.

B Littlewood JM, Crollick A, Richards IDG. Childhood coeliac disease is disappearing. Lancet $1980 ;$ ii : 1359.

7 Dossetor JFB, Gibson AAM, McNeish AS. Childhood coeliac disease is disappearing. Lancet $1981 ; \mathrm{i}: 322-3$.

${ }^{8}$ Barry RE, Baker P, Read AE. Coeliac disease: the clinical presentation. Clin Gastroenterol 1974;3:55-69.

- McConnell RB. Membership of the Coeliac Society of the United Kingdom. In: McConnell RB, ed. The genetics of coeliac disease. Lancaster: MTP Press, $1981: 65-9$.

(Accepted 13 October 1982) 